\title{
Promotion of Synaptic Maturation by Deep Seawater in Cultured Rat Hippocampal Neurons
}

\author{
Seong-Ho Kim, HyunSook Lee', Kyung Soo Nam², Yun Hee Shon² and II Soo Moon * \\ Departments of Internal Medicine and ${ }^{1}$ Anatomy, College of Medicine and ${ }^{2}$ Regional Innovation System, Dongguk University, Gyeongju, Korea. \\ Received August 29, 2008 / Accepted November 18, 2008
}

Deep seawater (DSW) refers to water extracted from the ocean, usually at depths of 200 meters or
more, which is rich in inorganic materials and has attracted attention for various applications. We in-
vestigated the effects of the DSW on the synaptic maturation of cultured rat hippocampal neurons.
Immunocytochemical examination of DIV 21 showed that PSD-95, aCaMKII, and synGAPa1 clusters
were strengthened and coupling rates of SV2 and NR2B were significantly increased in neurons
grown in the presence of H- 800 and H-1000 DSW. Our results indicate that DSW promotes the for-
mation of excitatory postsynaptic signal transduction complexes NRC/MASC and functional synapses.

Key words : CaMKII, deep seawater, hippocampal neuron, NR2B, SV2, synapse, synGAP 1

\section{Introduction}

While no specific definition exists, deep seawater (deep ocean water ;DSW) generally refers to seawater at depths of 200 meters or more, which is devoid of sunlight. Due to the consequent lack of photosynthesis, DSW is relatively free of microorganisms such as phytoplanktons. DSW is enriched in various minerals including indispensable trace elements, making it useful in a variety of applications [7]. The physiological efficacy of DSW has been illustrated. DSW controls the increase of serum lipid values [total cholesterol and low density lipoprotein (LDL) cholesterol] of cholesterol-fed rabbits, and promotes the reduction of serum lipid hyperlipemia rabbits [22]. Furthermore, DSW is useful for the prevention of hyperlipidemia and arteriosclerosis compared to the surface seawater by reduction of the LDL cholesterol level and enhancement of GPx activity [16]. Finally, DSW can improve cardiovascular hemodynamics [10] and indices for cancer chemoprevention [20].

We have been studying the effects of the DSW upwelled from the East Sea, located offshore of YangYang (KangWondo, Korea) on cultured rat hippocampal neurons. Using this model system we recently tested the efficacy of DSW on morphological differentiation; although DSW had no effect on initial morphological differentiation (17 h post-plating), low hardness (0 and 200) DSW reduced dendritic branching resulting in bipolar-like morphologies in extreme cases [14].

*Corresponding author

Tel : +82-54-770-2414, Fax : +82-54-770-2434

E-mail : moonis@dongguk.ac.kr
Hardness 600 DSW was more or less same as control groups, and hardness 1,000 DSW (H-1000) doubled the number of dendritic branches [14] indicating that DSW with appropriate hardness ameliorates neuronal health.

Synapses are specialized contact zones between neurons through which cell-cell communication is achieved in the central nervous system. Electron microscopy has revealed that synapses are junctions between neurons with membrane specializations at the transmitter-releasing presynaptic site and the postsynaptic region. Therefore, development of robust synapses is a pre-requisite of healthy neurons. Excitatory postsynaptic compartments are characterized by glutamate receptors (GluRs) such as $\alpha$-amino-3-hydroxy-5methyl-4-isoxazoleproprionic acid (AMPA) receptors (AMPARs), N-methyl-D-aspartate (NMDA) receptors (NRs) and group I metabotropic GluRs (mGluRs) [8,15]. For the NMDA- or MaGuk-associated (NRC/MASC) complex, PDZ-containing proteins of the MaGuk superfamily such as SAP90/PSD-95 (synapse-associated protein 90/postsynaptic density protein 95) serve as protein adapter sites [5,9]. SAP90/PSD-95 is the prototypical and best-characterized MaGuk protein that tethers NRs to the postsynaptic membrane $[4,13,18]$. Therefore, PSD-95 can be exploited as a standard marker for excitatory postsynaptic maturation.

The $\alpha$-isoform of type II $\mathrm{Ca}^{2+} /$ calmodulin-dependent protein kinase ( $\alpha$ CaMKII) and synGAP $\alpha 1$ interact with PSD-95. aCaMKII interacts with PSD-95 through another scaffold protein termed TANC [21]. SynGAP is a major component of the PSD at excitatory postsynaptic compartments, where it associates with the PDZ domains of PSD-95 [3,11,23]. 
SynGAP 01 is specifically associated with NR2B [12] and plays a critical role in the regulation of neuronal P38 mitogen-activated protein kinase (MAPK) signaling, AMPAR membrane trafficking, and excitatory synaptic transmission [19]. These molecules are good representatives for excitatory spines. Presently, analyses of these proteins through immunocytochemistry allowed us to investigate the efficacy of DSW on morphological maturation of synapses; we demonstrate that DSW promotes formation of NRC/MASC clusters and synapses.

\section{Materials and Methods}

\section{DSW}

DSW pumped up from a depth of 1,100 m off YangYang (Kwang Won-do, Korea) was desalinated and concentrated by reverse osmosis. The desalinated water (hardness 0 ) and hardness 4,000 DSW were obtained from Waterbis (AnSan, Korea). The mineral ingredient content of the hardness 4,000 DSW is presented elsewhere [20].

\section{Antibodies}

aCaMKII (1:500; mouse monoclonal 6G9), NR2B (1:1,000) and synGAPa (1:1,000; rabbit polyclonal) antibodies were purchased from Upstate Biotechnology (Lake Placid, NY, USA). Synaptic vesicle 2 (SV2) (1:500; mouse monoclonal) antibody was acquired from the Developmental Studies Hybridoma Bank, University of Iowa, Iowa City, IA, USA). PSD-95 (1:1,000; chicken polyclonal UCT-C1) antibody was a gift from Dr. Randall Walikonis, University of Connecticut).

\section{Neuronal culture}

Embryonic day 18 (E19) rat hippocampal cells were dissociated by triturating trypsin-treated tissues and were plated on poly-DL-lysine-coated coverslips (1,000-1,500 cells/ $\mathrm{mm}^{2}$ ) in minimal essential medium (MEM; Gibco, Carlsbad, CA, USA) containing $10 \%(\mathrm{v} / \mathrm{v})$ fetal bovine serum (FBS; Gibco), 25\% (v/v) DSW of various hardness's, and $25 \mu \mathrm{M}$ glutamate, as previously described $[1,6]$. One third of the culture medium was replaced every three days with fresh medium containing all components with the exception of glutamate.

\section{Immunocytochemistry}

Cells were fixed using the PFA/MeOH method [17].
Briefly, coverslips were rinsed briefly in phosphate buffered saline (PBS) and fixed with $4 \%$ paraformaldehyde (PFA) in PBS at room temperature (RT) for $10 \mathrm{~min}$. Coverslips were rinsed in PBS and then incubated in $-20^{\circ} \mathrm{C}$ methanol at $-20^{\circ} \mathrm{C}$ for $20 \mathrm{~min}$. The cells were then rinsed once with PBS and blocked overnight at $4^{\circ} \mathrm{C}$ in preblocking buffer [5\% normal goat serum, $0.05 \%$ Triton X-100 in H-PBS $(450 \mathrm{mM} \mathrm{NaCl}$ and $20 \mathrm{mM}$ phosphate buffer, $\mathrm{pH}$ 7.4)]. Primary antibodies were diluted in preblocking buffer $(250 \mu \mathrm{l}$ per well of 24-well culture plate), replaced with preblocking buffer, and incubated overnight at $4^{\circ} \mathrm{C}$. Coverslips were rinsed $(15 \mathrm{~min} \times 3$ ) in preblocking buffer, and incubated with secondary antibodies [Alexa Fluor 488-conjugated goat anti-mouse, Alexa Fluor 568 conjugated-goat anti-rabbit, and Alexa Fluor 647-conjugated goat anti-chicken IgG (each diluted 1:1,000 in blocking buffer; Invitrogen, Carlsbad, CA, USA)] at RT for 1-2 hr. Coverslips were rinsed once in preblocking buffer for $15 \mathrm{~min}$, twice in PBS, and mounted on slides with $4 \%$ n-propylgallate in $90 \%$ glycerol and $10 \%$ sodium carbonate buffer ( $\mathrm{pH}$ 8.7).

\section{Fluorescence light microscopy}

A Leica DM IRE2 research microscope (Leica Microsystems AG, Wetzlar, Germany) equipped with filter systems I3 S, N2.1 S, and Y5 was used to capture light and fluorescent microscopic images. Digital images were acquired with low power (10X) and a HCX PL FL 100X oil-immersion lens and a high-resolution CoolSNAP ${ }^{\mathrm{TM}} \mathrm{CCD}$ camera (Photometrics, Otoobrunn, Germany) under the control of a computer equipped with FW4000 software (Leica). Images $(1,388 \times 1,039$ pixels $)$ were processed with the use of Photoshop 5.0 (Adobe Systems, San Jose, CA, USA). For histograms and surface plots, images were converted into gray modes and the white and gray was inverted using PhotoShop. Backgrounds were subtracted in the two-dimensional rolling ball mode using a Scion Image program (Scion, Frederick, MD, USA). Histograms were produced as a density scale of 255 , and surface plots in the wire frame mode using Scion Image.

\section{Statistical analyses}

The numbers of SV2 clusters that either overlapped with or were adjacent to NR2B ones in typical pyramidal neurons were counted (10 areas of approximately $20 \mu \mathrm{m} \times 20 \mu \mathrm{m}$ ), and are expressed as a percentage of the total $($ mean $\pm \mathrm{SD}$ ). Multiple pairwise comparisons for statistical significance 
were evaluated by Kruskal-Wallis one-way ANOVA, and the differences between groups by Mann-Whitney $U$-test. The $\mathrm{p}$ values of $<0.05$ and $<0.01$ were considered to be significant and very significant, respectively.

\section{Results and Discussion}

The East Sea is connected with four other open seas through narrow and shallow straits. Due to relatively isolated oceanography, it is a bowl-shaped 'Ocean Miniature' where water exchange between the East Sea and other connected oceans is very limited. Therefore, it is believed that more than $90 \%$ of all East Sea water is DSW. In the previous report [14] we showed that the rat hippocampal neurons grown in the presence of the East Sea DSW are healthier and more dendritic branches are formed than distilled water (DW) groups. In this study we investigated whether the health in gross morphology accompanies synaptic 'health' or maturation. Because DSW [25\% (v/v)] needs to be added into the culture medium, culture media were made using a powder form [minimal essential medium (MEM; Gibco, \#11700-077) containing 10\% (v/v) fetal bovine serum (Gibco \# 26140-079). This medium is not optimal for neuronal growth compared to Neurobasal, although neurons do survive and differentiate. Ironically, this condition is a good model for testing neurosupportive agents because once can observe amelioration of neuronal growth. Using this model system we recently tested the efficacy of DSW on morphological differentiation of cultured rat hippocampal neurons [14].

DSW promotes the formation of NRC/MASCcomplex at the spine

Our previous study [14] showed that low hardness (0 and 200) DSW upwelled from the East Sea, offshore YangYang (Korea), had negative effects on the gross morphological differentiation when rat hippocampal neurons were grown in the minimal essential medium containing $10 \%(\mathrm{v} / \mathrm{v})$ fetal bovine serum and 25\% (v/v) DSW. However, hardness 1,000 DSW had positive effects resulting in more dendritic branches, while hardness 600 DSW was more or less same as control (DW) groups. Therefore, in this study we chose hardness 800 and 1,000 to investigate synaptic maturation. For markers for NRC/MASC-complex we chose PSD-95, aCaMKII, and synGAP $\alpha 1$.

The expression profiles of PSD-95, aCaMKII, and synGAP $\alpha 1$ are shown in Fig. 1, 2, and 3, respectively. The three proteins exhibited very similar expression profiles each other. In control cultures (DW), where no DSW was added in the medium, formation of immunoreactive clusters or spots was weak (panel A of Fig. 1-3). The histogram (panel B of Fig. 1-3) showed that the mean densities for control groups were

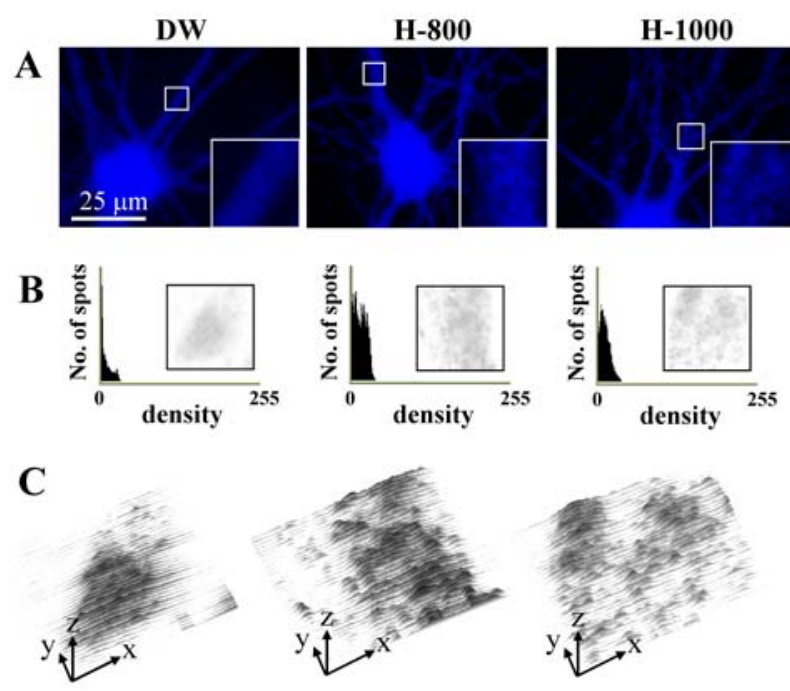

Fig. 1. Fluorescent microscopic images showing expression profiles of PSD-95. E18 rat hippocampal neurons were grown in DMEM with 10\% (v/v) BSA and either 25\% (v/v) DW, H-800DSW, or H-1000 DSW. (A) Cells were fixed on DIV21 and immunostained with anti-PSD-95 antibody. Boxed areas are shown enlarged in insets. Scale bar depicts $25 \mu \mathrm{m}$. (B) Histograms representation of the data. Boxed areas in A were converted into 255 gray scale, black and white were inverted, and histograms were obtained. (C) The processed images in B were used for surface plots.

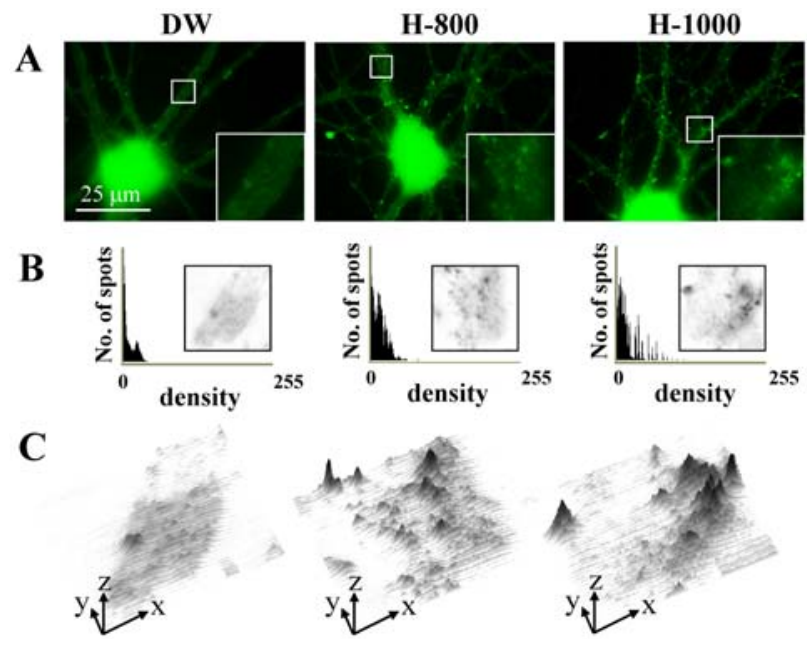

Fig. 2. Fluorescent microscopic images showing expression profiles of $\alpha$ CaMKII. Annotations are same as in Fig. 1. 


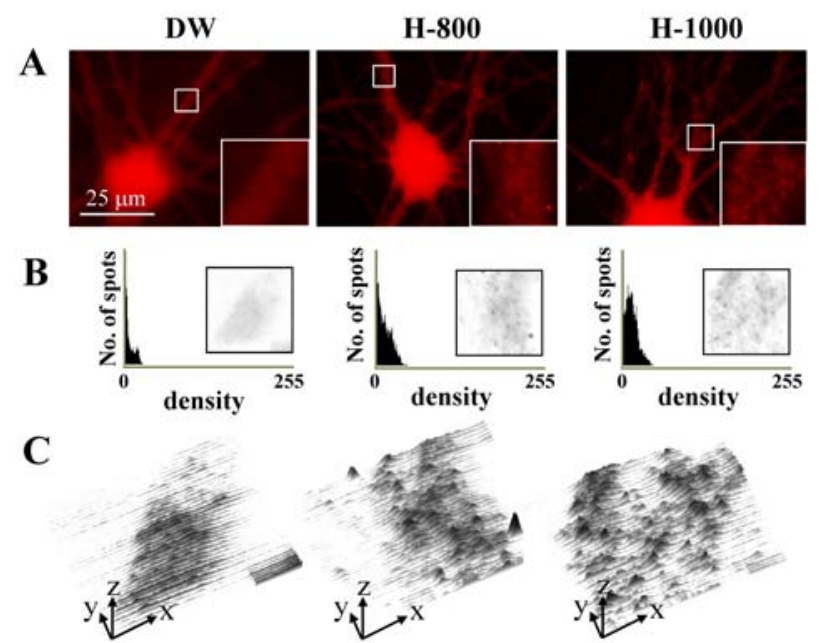

Fig. 3. Fluorescent microscopic images showing expression profiles of synGAPa1. Annotations are same as in Fig. 1.

8.59, 10.47, and 6.65 for PSD-95, $\alpha$ CaMKII, and synGAP $\alpha 1$, respectively. The mean densities for hardness 800 (H-800) groups were 10.01, 13.21, and 11.63 for PSD-95, aCaMKII, and synGAP $\alpha 1$, respectively, while the mean densities for hardness 1,000 (H-1000) groups were 10.46, 16.76, and 12.28 for PSD-95, aCaMKII, and synGAPa1, respectively. Increases in the mean densities of immunoreactive spots indicate that more protein molecules are recruited at the spine. In addition, the surface plots for each immunocytochemistry images clearly visualized the increases in the height of each peak that represent individual spots (panel $C$ of Fig. 1-3). These results indicate that DSW promotes formation of NRC/ MASC-complexes.

\section{DSW promotes synapse formation}

Synapses are communication sites for neurons in networks. Therefore, development of robust synapses is the prerequisite of neuronal health. To investigate whether DSW affects the formation of synapses, we carried out immunocytochemistry to stain cultured rat hippocampal neurons with antibodies against specific markers for pre- and postsynaptic compartments. For presynaptic marker, we selected SV2, a protein present in the synaptic vesicles at both excitatory and inhibitory axon terminals [2]. For a marker for postsynaptic compartment we used NR2B, which is a member of the NRC/MASC-complex [13]. Fluorescent microscopic images of double-labeling of hippocampal neurons with antibodies against NR2B and SV2 were shown in Fig. 4. Immunoreactive signals for both NR2B and SV2 were weak in the DW control group, indicating that both pre- and
Fig. 4. Fluorescent microscopic images showing double-labeling of cultured hippocampal neurons. E18 rat hippocampal neurons were grown and fixed as described in Fig. 1. (A) Cells were double-stained with antibodies against SV2 and NR2B. Single channels and merged images are shown. Boxed areas are shown enlarged in insets at the bottom. Coupled SV2 (green arrowhead) and NR2B (red arrowhead) immunoreactive clusters are shown in single and merged channels. Scale bar, $25 \mu \mathrm{m}$. (B) Ten random areas were chosen, coupled SV2 and NR2B immunoreactive clusters were counted, and expressed as percentages of total SV2 counts. ${ }^{* *}, p<0.01$.

postsynaptic compartments are not well developed. Merge of the two images showed that most of the SV2 clusters did not overlap with or neighbor to NR2B clusters $(16.6 \pm 0.8 \%$ overlap). In contrast, neurons grown in the presence of DSW with hardness 800 (H-800) and 1,000 (H-1000) exhibited robust immunoreactive signals for both antigens, indicating that both pre- and postcompartments are well formed (Fig. 4 H-800 and H-1000). Merge of SV2 and NR2B images showed that coupling of the two antigens are frequent ( $34.4 \pm 1.7 \%$ and $58.0 \pm 1.8 \%$ overlap, respectively). These are very significant $(p<0.01)$ increases from DW control groups (Fig. 4B). When compared H-800 and H-1000, the latter ex- 
hibited still a significant $(p<0.01)$ increase in the rate of coupling of the two antigen. These results indicate that DSW promotes formation of functional synapses, while hardness 1000 is better than 800 in this regard.

\section{Conclusion}

The present study shows that DSW upwelled in the off-shore YangYang promotes clustering of NRC/MASCcomplexes and formation of synapses. Since the formation of synapses is a prerequisite for neuronal health, DSW may support neuronal functions.

\section{Acknowledgement}

This work was supported by the Regional Innovation System (RIS) funded by the Ministry of Knowledge Economy (06-RIS-02), Republic of Korea.

\section{References}

1. Brewer, G. J., J. R. Torricelli, E. K. Evege and P. J. Price. 1993. Optimized survival of hippocampal neurons in B27-supplemented Neurobasal, a new serum-free medium combination. J. Neurosci. Res. 35, 567-576.

2. Buckley, K. and R. B. Kelly. 1985. Identification of a transmembrane glycoprotein specific for secretary vesicles of neural and endocrine cells. J. Cell Biol. 100, 1284-1294.

3. Chen, H.-J., M. Rojas-Soto, A. Oguni and M. B. Kennedy. 1998. A synaptic Ras-GTPase activating protein (p135 SynGAP) inhibited by CaM kinase II. Neuron 20, 895-904.

4. Cho, K. O., C. A. Hunt and M. B. Kennedy. 1992. The rat brain postsynaptic density fraction contains a homolog of the Drosophila discs-large tumor suppressor protein. Neuron 9, 929-942.

5. Farr, C. D., P. R. Gafken, A. D. Norbeck, C. E. Doneanu, M. D. Stapels, D. F. Barofsky, M. Minami and J. A. Saugstad. 2004. Proteomic analysis of native metabotropic glutamate receptor 5 protein complexes reveals novel molecular constituents. J. Neurochem. 91, 438-450.

6. Goslin, K., H. Asmussen and G. Banker. 1998. Rat hippocampal neurons in low-density culture. In Banker, G. and K. Goslin. Culturing nerve cells, 2nd eds., pp.339-370, Cambridge, MA: MIT Press.

7. Hachmuth, C. 1991. On the properties of deep seawater at Keahole point. In: Proceeding of the International Forum on Deep Sea Water, pp.46-49.

8. Hollmann, M. and S. Heinemann. 1994. Cloned glutamate receptors. Annu. Rev. Neurosci. 17, 31-118.

9. Husi, H., M. A. Ward, J. S. Choudhary, W. P. Blackstock and S. G. Grant. 2000. Proteomic analysis of NMDA re- ceptor-adhesion protein signaling complexes. Nat. Neurosci. 3, 661-669.

10. Katsuda, S., T. Yasukawa, K. Nakagawa, M. Miyake, M. Yamasaki, K. Katahira, M. Mohri, T. Shimizu and A. Hazama. 2008. Deep-sea water improves cardiovascular hemodynamics in Kurosawa and KusanagiHypercholesterolemic (KHC) rabbits. Biol. Pharm. Bull. 31, 38-44.

11. Kim, J. H., D. Liao, L. -F. Lau and R. L. Huganir. 1998. SynGAP: a synaptic RasGAP that associates with the PSD-95/SAP90 protein family. Neuron 20, 683-691.

12. Kim, M. J., A. W. Dunah, Y. T. Wang and M. Sheng. 2005. Differential roles of NR2A- and NR2B-containing NMDA receptors in Ras-ERK signaling and AMPA receptor trafficking. Neuron 46, 745-760.

13. Kornau, H. C., L. T. Schenker, M. B. Kennedy and P. H. Seeburg. 1995. Domain interaction between NMDA receptor subunits and the postsynaptic density protein PSD-95. Science 22, 1737-1740.

14. Lee, H., K. S. Nam, Y. Shon and I. S. Moon. 2008. Deep seawater increases dendritic branches of cultured rat hippocampal neurons. J. Life Sci. 18, 897-901.

15. Mayer, M. L. and N. Armstrong. 2004. Structure and function of glutamate receptor ion channels. Annu. Rev. Physiol. 66, 161-181.

16. Miyamura, M., S. Yoshioka, A. Hamada, D. Takuma, J. Yokota, M. Kusunose, S. Kyotani, H. Kawakita, K. Odani, Y. Tsutsui and Y. Nishioka. 2004. Difference between deep seawater and surface seawater in the preventive effect of atherosclerosis. Biol. Pharm. Bull. 27, 1784-1787.

17. Moon, I. S., S. J. Cho, I. Jin and R. A. Walikonis. 2007. A simple method for combined fluorescence in situ hybridization and immunocytochemistry. Mol. Cells 24, 76-82.

18. Niethammer, M., E. Kim and M. Sheng. 1996. Interaction between the $C$ terminus of NMDA receptor subunits and multiple members of the PSD-95 family of membrane-associated guanylate kinases. J. Neurosci. 16, 2157-2163.

19. Rumbaugh, G., J. P. Adams, J. H. Kim and R. L. Huganir. 2006. SynGAP regulates synaptic strength and mitogen-activated protein kinases in cultured neurons. Proc. Natl. Acad. Sci. USA 103, 4344-4351.

20. Shon, Y. -H., M. -K. Kim, J. -S. Jang, E. -J. Jung and K. -S. Nam. 2008. Effect of Deep Sea Water on Phase I, Phase II and Ornithine Decarboxylase. J. Life Sci. 18, 381-386.

21. Suzuki, T, W. Li, J. P. Zhang, Q. B. Tian, H. Sakagami, N. Usuda, H. Kondo, T. Fujii and S. Endo. 2005. A novel scaffold protein, TANC, possibly a rat homolog of Drosophila rolling pebbles (rols), forms a multiprotein complex with various postsynaptic density proteins. Eur. J. Neurosci. 21, 339-350.

22. Yoshioka, S., A. Hamada, T. Cui, J. Yokota, S. Yamamoto, M. Kusunose, M. Miyamura, S. Kyotani, R. Kaneda, Y. Tsutsui, K. Odani, I. Odani and Y. Nishioka. 2003. Pharmacological activity of deep-sea water: examination of hyperlipemia prevention and medical treatment effect. 
Biol. Pharm. Bull. 26, 1552-1559.

23. Zhang, W., L. Vazquez, M. Apperson and M. B. Kennedy. 1999. Citron binds to PSD-95 at glutamatergic synapses on inhibitory neurons in the hippocampus. J. Neurosci. 19, 96-108.

초록 : 해양심층수의 해마신경세포 연접형성 촉진 효과

김성호 $\cdot$ 이현숙 ${ }^{\prime}$ 손윤희 ${ }^{2} \cdot$ 남경수 $^{2} \cdot$ 문일수 ${ }^{*}$

(동국대학교 의과대학 내과학교실, ${ }^{1}$ 해부학교실, ${ }^{2}$ 동국대학교 지역연고산업진흥사업단, 난치병한양방치료연 구센터 및 의과대학 약리학교실)

해양심층수(deep seawater, DSW)는 청정성, 풍부한 무기물질 및 필수미량원소의 함유로 음료를 포함한 여러 분야에 응용하기 위하여 최근 많은 관심을 받고 있다. 본 연구실에서는 동해 양양 부근의 해저 $1,100 \mathrm{~m}$ 에서 취수하여 역삼투압 시스템으로 탈염과 농축을 한 심층수가 경도 600-1,000에서 배양한 흰쥐해마신경세포의 형태적 분화에 도움을 줌을 보고한 바 있다. 좀 더 구체적인 영향을 조사하기 위하여 본 연구에서는 경도 800 및 1,000 심층수가 $25 \%(\mathrm{v} / \mathrm{v})$ 포함된 minimal essential media에서 배양한 해마신경세포에서의 연접형성을 대조군(증류수 첨가)과 비교하였다. 경도 800 및 1000에서 자란 신경세포는 흥분성 연접후세포막의 신호전달복합체인 NRC/MASC 크러스 터의 형성을 촉진하였다. 또한 연접전/후 구조가 밀접히 짝을 이룬 연접이 매우 현저히 $(\mathrm{p}<0.01)$ 증가하였다. 이 결과는 심층수가 연접의 형성을 촉진하여 신경세포의 건강에 도움을 주는 것으로 해석된다. 